\title{
Sound Changes to Avoid Using Taboo Characters
}

\section{Tokio TAKATA}

Fudan University

Shanghai, China

DOI: $10.17816 /$ WMO77307

Received 11.06.2021.

Abstract: It has been recognized so far that sound change was not used in order to avoid using a taboo character. Nevertheless, we find examples that suggest that there was indeed a habit of changing sounds to avoid using taboo characters in speech. Such sound changes can be seen not only in the case of state taboo, i.e., avoidance of the given names of emperors, but also in the case of secular taboo, e.g., sound changes of the vocabularies for genitals practiced in the Buddhist society. Interesting enough, these sound changes were not a case of temporary substitution but were used as one of the stable pronunciations of the characters.

Key words: taboo characters, sound change, state taboo, secular taboo, Dunhuang Manuscripts, Buddhist society

For citation: Tokio Takata. "Sound Changes to Avoid Using Taboo Characters". Pis'mennye pamiatniki Vostoka, 2021, vol. 18, no. 3 (iss. 46), pp. 51-57 (in English). DOI: 10.17816/WMO77307

About the author: Tokio TAKATA, Distinguished Professor Fudan University, Department of History (Shanghai, China) (takatatokio@gmail.com).

() Tokio Takata, 2021

\section{Preamble}

The taboo characters are peculiar to Chinese textual history, and an understanding of their various usages has been essential to the Chinese philological study. In this essay, I will discuss the issue of the taboo characters in the Chinese history, specifically the relationship between the sound changes and taboo characters.

Until now, it has been accepted that a sound change was not used in order to avoid using a taboo character. For instance, Chen Yuan 陳垣, in his famous standard work on this problem, Shihui juli 史諱舉例 “Examples of Taboos in History," claims that sound changes to avoid using taboo characters were not practiced at all ${ }^{1}$. In this essay, I ask if this theory can

\footnotetext{
${ }^{1} 2^{\text {nd }}$ edition, Zhonghua shuju 中華書局, 1962, p. 8.
} 
still be considered accurate, and try to demonstrate that the practice of changing sounds to avoid using taboo characters was present in the past, especially in Medieval China. This paper is mainly concerned with the "state taboo," i.e., the avoidance of emperors' names, but "secular taboo" in Buddhist society will also be discussed.

\section{State taboo}

In premodern China, the given names of emperors were to be avoided. These customs were carried forward from dynasty to dynasty, and took root in many periods of Chinese history. However, there were some methods to avoid them:

1. To change the character to another synonymous character. For example, the character 治 $z h i$, the name of emperor Gaozong of Tang dynasty, was replaced with the synonym 理 li.

2. To omit a stroke of the character, in many cases the last stroke of the character. For example the character 民, which is the second character of emperor Taizong's name 世民, is written as the shape displayed in Fig. 1. This method is called quebi 䦕筆. We can attest to the existence of the quebi method from evidence in both the Dunhuang manuscripts, as well as in old manuscripts of Chinese texts kept in Japan.

3. In some other cases, the taboo characters were also left blank.

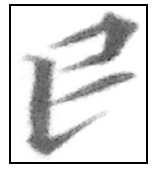

Fig. 1: From an old manuscript of the Qunshu zhiyao 群書治要 kept in Tōkyō National Museum.

We will now examine further examples of taboo characters. These examples are from Foding zunsheng tuoluoni 佛頂尊勝陀羅尼經 (Skr. Ușṇiṣa Vijaya Dhāraṇī Sūtra), translated by Rizhao 日照 and Du Xingyi 杜行顗 in the 4th year of Yifeng 儀鳳 (679):

1. Shizun 世尊 is written as shengzun 聖尊 in order to avoid the name of Li Shimin 李世民.

2. Shijie 世界 is written as shengjie 生界, also in order to avoid the name of Li Shimin.

3. Jiuzhi 救治 is written as jiuchu 救除 in order to avoid the name of Lizhi 李治.

4. Dashi 大勢 is written as daqu 大趣 in order to avoid the name of Li Shimin.

The last example is worth noting, as the avoidance is also applied to the homophonous character shi 勢. In such cases, the homophonous character is called “xianming” 嫌名.

We can also find a large number of examples of quebi in Zangjing yinyi suihanlu 藏經音義隨函録 (Phonetic and semantic glosses to the Tripitaka arranged in the order of the bookcases) compiled by Kehong 可洪 between 931 and 940 CE.

For example, in a gloss to Sengjiatuo jing 僧伽吒經 (Sanghāta sutra), we find: 【虎形】上呼古反, 獸名, 正作虎也, 避廟諱故省之。“The upper character is pronounced as $h u$ with the fanqie spelling 呼古, name of an animal, the correct form is 虎. A stroke is omitted due to the taboo character for a former emperor". ${ }^{2}$

${ }^{2} \mathrm{Hu}$ 虎 is the name of an ancestor of the Tang dynasty. Although Kehong was a monk of the Later Jin 後晉 dynasty of the Five dynasties, he still followed the Tang rules regarding taboo characters. 


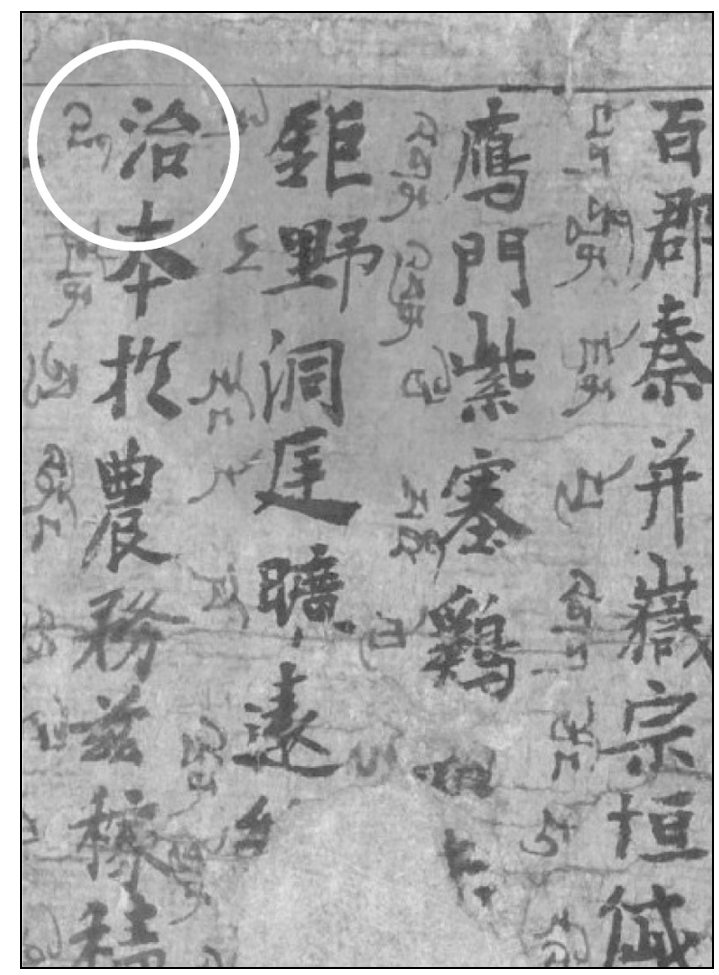

Fig. 2: Pelliot Tibétain 1046.

Taken from Gallica of the BnF.

And in a gloss to Pusa chutai jing 菩薩處胎經: 【處廿】下户制反，正作世, 避太宗諱故關。“the lower character is pronounced as shi with the fanqie spelling 尸制, the correct form is \#. A stroke is omitted due to the name of Emperor Taizong". 3

While these methods were practiced in writing, it is not easy to trace how the taboo characters were avoided in speech. However, certain literary materials suggest that there was indeed a habit of changing sounds to avoid using taboo characters in speech as well.

Such a sound change can be surmised from the Tibetan transcription of a character in the Dunhuang manuscript text of the Thousand Character Classics, Qianziwen (Fig. 2). Here the character 治, the name of the Tang emperor Gaozong, was read as $l i$ instead of chi or $z h i$, the genuine pronunciation of the character. ${ }^{4}$ The $l i$ sound is the pronunciation of the synonymous character 理. It seems to me that this single example can dispute the validity of Chen Yuan's theory. Until now, the sound $l i$ was recognized as a temporary substitute for the avoidance phenomenon, but that is not the case.

The sound $l i$ was by no means a temporary substitute, but in fact was used as one of the stable pronunciations of the character. This can be confirmed by the frequent use of the character for substituting other characters with the $l i$ pronunciation in the Dunhuang manuscripts.

\footnotetext{
${ }^{3}$ Needless to say, Shiming 世民 is the name of Taizong of the Tang dynasty.

${ }^{4}$ As to the character 治, there are three different readings in the rime dictionary Kanmiu buque Qieyun 刊謬補缺切韻 of Wang Renxu 王仁昫, one in the level tone and two in the departing tone. The present pronunciation $c h i$ is derived from the reading of the even tone and $z h i$ from that of the departing tone. Still, as all three entries are annotated in a manner similar to “理, 大帝諱” (same as $l i$ 理, also the name of the Great emperor, i.e., Gaozong), it is hard to determine which reading of the three is correct.
} 


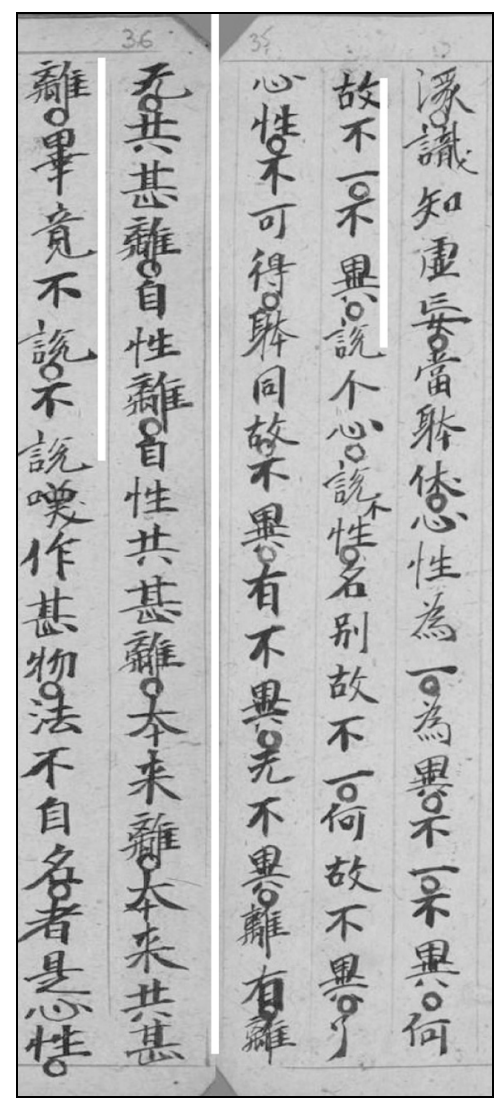

(a) P3861

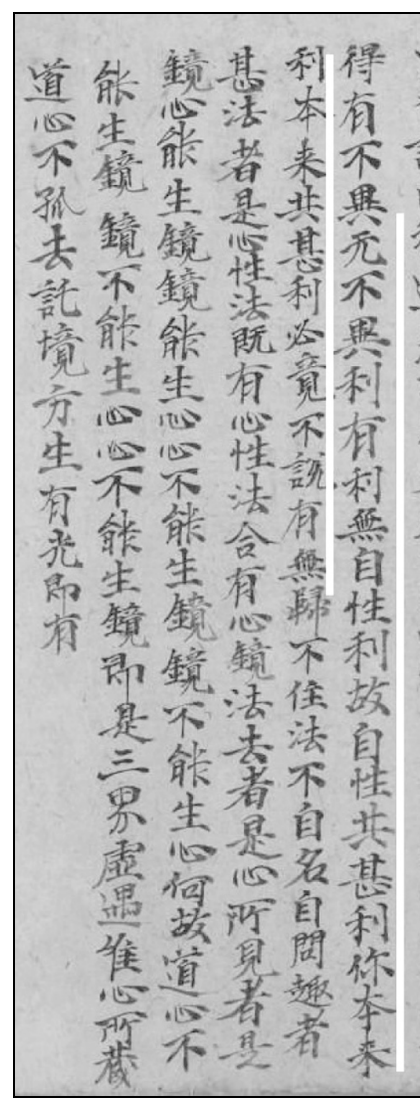

(b) P3215

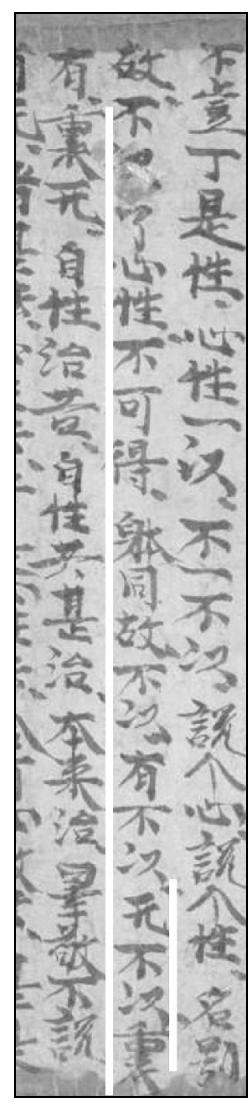

(c) P3373

Fig. 3: Pelliot Chinois 3215, 3373, 3861. Taken from Gallica of the BnF.

Let us examine a passage of a Zen catechism text, Dacheng sanke 大乘三科, “Three fundamentals of Mahayana Buddhism." Here I present three different manuscripts of the text: (a) P3861, (b) P3215, and (c) P3373 (Fig. 3), and the passage can be read as follows:

(a)「離有, 離无, 共甚離, 自性離。」「自性共甚離? 「本來共甚離? 「畢 竟不說.......」

(b)「利有，利无，自性利故。」「自性共甚利你？」「本來利。」「本來共甚利 ?」「果竟不說.......」

(c)「裏有，裏无，自性治苦。」「自性共甚治？」「本來治。畢敬不說......」

There is also a text written in the Tibetan script (d) C131, currently housed in the British Library. ${ }^{5}$ Here, the word in question was transcribed as $l i$ as a matter of course.

(d) “yi’u pu yi / wu pu yi / li” i’u li wu / dzi zye li khu / dzi zye gyung zhim lyi /bun la'u lyi /bun la'u gyung zhim lyi / 'pyir gye pu shwar 「離有, 離无, 自性離苦。」「自性共甚離？」「本來離。」「本來共甚離？」 「果竟不說。

${ }^{5}$ This is only a part of the manuscript C131 (Long Scroll), Recto 11.251-253. 

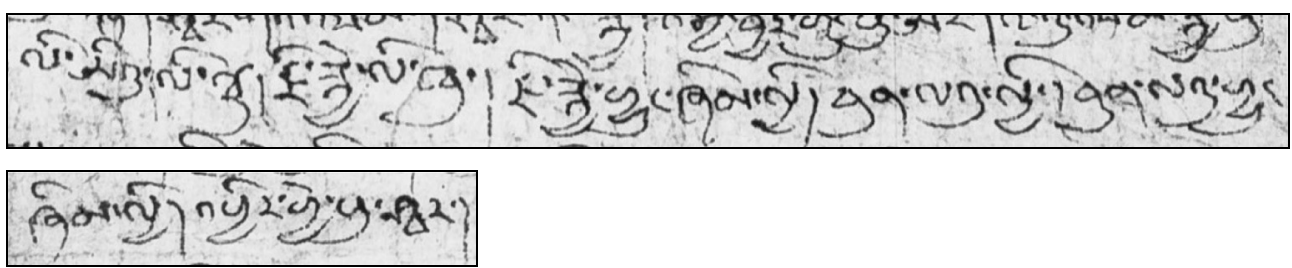

Fig. 4: C131 (IOL Tib J 1772). Taken form TAKATA Tokio, A Study on the Chinese 'Long Scroll' 長巻 in Tibetan Script, Part 1: Text and Facsimile. Tōhō Gakuhō (東方學報), No. 65, March 1993.

As homophonous characters are used frequently in each text and the text itself varies slightly, it is not easy to grasp the meaning of the catechism. ${ }^{6}$ Among these three (or four) manuscripts, the manuscript (a) can be considered the most easily understandable, in which the correct characters are generally used. In the two other manuscripts, 利 is used for 離, and 裏 for 離. The crucial point, however, is that in manuscript (c) 離 is written as 治. In this manuscript, the very character 治 is used for the sound li. It can be stated without doubt that the character 治 was pronounced in practice as $l i$.

Now let us add some more examples from Dunhuang manuscripts.

1. “舎卻治（麗）亶毛錦裖” Дx278(1) 好住娘・入山讚

2. “緋治（麗）亶毛一領” S1947V(1) 唐咸通四年癸未歳 (863) 敦煌所管十六寺和三所 禪窟以及抄録再成亶數目

3. “修治（理）佛手塑師及羅筋匠、染布匠等用” P2040V 淨土寺諸色入破暦赫會稿

4.“若右（有）親因（姻）論治（理）此舍來者、一仰丑撻並隣 [近]覓上好舍充 替一院” BD8347V 宋開寶八年 (875) 三月一日鄭醜撻出賣宅舍地基與沈都和契

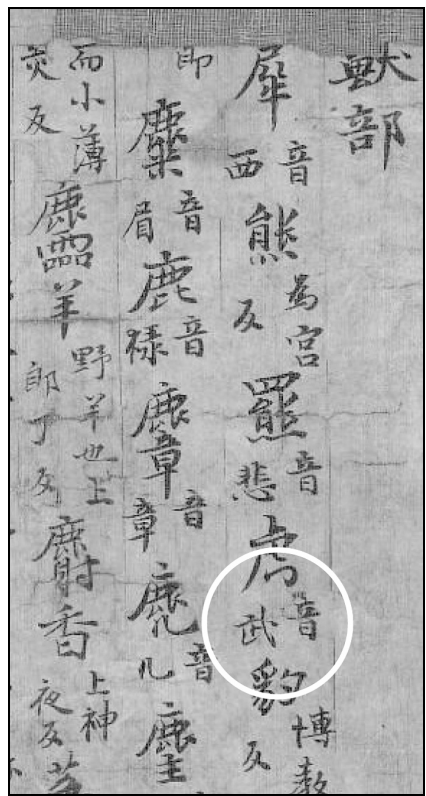

Therefore, $l i$ could not have been a temporary substitute, but was indeed used as one of the stable pronunciations of the character. This can be confirmed by the frequent use of the character to substitute other characters of $l i$ pronunciation in the Dunhuang manuscripts.

Conventionally, the applicable period of the avoidance of the taboo character 治is recognized to be from the 23rd year of Zhenguan 貞觀 $(649 \mathrm{CE})$ until the 1st year of Yuanhe 元和 (806 CE). However, the examples of the Dunhuang MSS cited above are much later than this period. We can therefore assume the $l i$ sound for the character 治 as a stable pronunciation.

Now let us discuss another taboo character of the Tang dynasty: 虎 $h u$ is the name of the grandfather of Li Yuan 李淵, founder of the Tang dynasty. In Tang times, the character was often changed to 獸、武、豹 or 虎. More frequently, the last stroke of the character

Fig. 5: Pelliot Chinois 2609. Taken from Gallica of the BnF.

\footnotetext{
${ }^{6}$ An approximate meaning of the phrase in question would be: "To leave beingness and to leave nothingness. In own-being, you can leave pain. From what can we leave? You can leave from the very beginning. From what can we leave from the very beginning? After all, it cannot be told".
} 
was omitted, as is the case with the quebi method. However, this character too was read not as $h u$ but as $w u$, the pronunciation of a substitute character 武. We may cite an entry of the popular dictionary of the Tang period, Suwu yaominglin 俗務要名林 (Indispensable words for secular affairs), discovered at Dunhuang. The character in question appears in two manuscripts, and in both manuscripts, the character 虎 is instructed to be pronounced $w u$. Here we present a part of P2609 in Fig. 5. The character itself also takes a quebi form. As this is a pronunciation in the dictionary, we cannot consider this as a case of temporary substitution.

\section{Secular taboo}

In addition to the state taboo of the emperor's given names, we can find another example of sound change, this time concerned with secular taboo. According to the Five Precepts of Buddhism, one must avoid sensual misconduct. Therefore, Buddhist monks largely refrained from using explicit sexual terms in their society. Such terms were considered suhui 俗諱 “secular taboo” and were to be avoided.

In Huilin's Yiqiejing yinyi ${ }^{7}$ 慧琳 《一切經音義》, juan 100, we find the following entry:

【裸形】「魯果反。赤體無衣曰裸, 或從人作倮, 或從身作躶, 今避俗諱, 音胡 瓦反, 上聲。」

[Luoxing]: To be pronounced *lwâ with the fanqie 魯果. *Lwâ means "body without any clothes," sometimes written倮 with the radical 人 or 躶 with the radical 身. Now pronounced *hwâ with the fanqie 胡瓦. Belongs to the rising tone.

On the other hand, in Kehong's Xinji Zangjing yinyi Suihanlu ${ }^{8}$ 可洪《新集藏經音義隨函録》, Book 25, we find:

【躶形】「上郎果反, 俗謂陰囊爲躶也。古文作胞, 像形字也。《說文》「赤體 。躶, 裸也。」又肥, 是身之少分, 亦不合偏露其躶也。今宜作裸, 音踝, 裸即全 體無衣也。」

[Luoxing]: The upper character is to be read as *lwâ with the fanqie 郎果, and refers to testicles in vulgar speech. In ancient character it was written as 胞, representing the figure. Shuowen jiezi 説文解字 says [...] Now it must be written as 裸, the pronunciation is *hwa 踝.

Here we find that the real meaning is given, whereas Hulin did not mention the meaning explicitly, only indicating the *hwâ sound as a substitution.

We find also in Kehong, Book 21:

【胆腂】「上徒旱反, 下胡瓦反, 偏露其體也。正作祖裸也。又上七余、七慮二 反。下諸家經音並作郎果反，非也，二並同。」

[Danluo]: [...] the lower character is to be read as *lwa,$[\ldots]$ correctly to be written as 祖裸. As to the lower character, many phonetic glosses indicate the sound $* l w \hat{a}$, but it is not correct.

We have another example of "secular taboo" for a Buddhist monk, again from Kehong, this time in Book 10:

【兩圓】「或作圓, 同于拳反。天體也, 核也, -也。正言通, 避俗諱, 故作圓 也。遄戸官反。」

\footnotetext{
${ }^{7}$ Completed in the second year of the Yuanhe 元和 era of theTang Dynasty (807 CE).

${ }^{8}$ Completed in the fifth year of the Tianfu 天福 era of the Later Jin (940 CE).
} 
[Liangyuan]: Alternatively written as 圓, both being pronounced as *jiwän with the fanqie 于拳. Celestial body, kernel, ball. Correctly written as, but written as 圓 in order to avoid secular taboo. 洏is pronounced *hwân by the fanqie 戸官.

兩圓 appears in the Pusa dichi jing 菩薩地持經 (Bodhisattva-bhūmi) translated by Tanwuchen 曇無讖 (Dharmakșema, 385-433 CE), and is referred to as one of the Eighty noble qualities 八十隨好 of Buddha. Xuanzang 玄牀 translates this term as 兩核 in his Yujia shidi lun 瑜伽師地論 (Yogācārabhūmi-śāstra). The term also certainly means "testicles,” as the commentary by Binfashi 賓法師, Sifenlüshu shizong yiji 四分律疏飾宗義記 provides the gloss: he wei luan ye 核謂卵也 “he" means “luan” (testicles). As a matter of fact, this term is translated differently in Chinese Buddhist sutras. Pusa shanjie jing 菩薩善戒經, translated by Qiunabamo 求那跋摩 (367-431 CE) gives yaoqizhong 腰奇中 “the very center of waist.” Faji mingshu jing 法集名數經, translated by Shihu 施護 of Nothern Song gives yinchu 隱處 “secret part.” Nevertheless, it is beyond doubt that both term

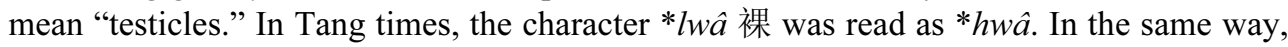
yuan 圓 was used in place of huan to avoid the taboo pronunciation.

\title{
Conclusion
}

The method of sound change was undoubtedly practiced to avoid using the taboo characters. The pronunciation $l i$ for the character 治 is widely observed and attained a stable position in the lexicon. The character 虎 was also read as $w u$ in place of $h u$, and the $w u$ pronunciation was even registered in a dictionary. Sound changes to avoid using taboo characters can also be observed in Chinese Buddhist society.

\section{Звуковые изменения вместо использования табуированных иероглифов}

\author{
Токио ТАКАТА \\ Фуданьский университет \\ Шанхай, Китай
}

Статья поступила в редакцию 11.06.2021.

Аннотация: До сих пор существовало мнение, что звуковые изменения не использовались для передачи табуированных иероглифов. Тем не менее мы обнаружили примеры, указывающие на то, что в разговорной речи часто обращались к звуковым изменениям, чтобы передать табуированные иероглифы, используемые в письменной речи. Такие замены отмечаются не только относительно государственных табу, но и в бытовых случаях, например изменения буддистами звучания слов в обозначении половых органов. Интересно, что такие звуковые изменения были не временными явлениями, а постоянно использовались при произнесении конкретных иероглифов.

Ключевые слова: табуированные иероглифы, звуковые изменения, государственные табу, частные табу, дуньхуанские рукописи, буддийское общество.

Для цитирования: Tokio Takata. Sound Changes to Avoid Using Taboo Characters // Письменные памятники Востока. 2021. Т. 18. № 3 (вып. 46). С. 51-57 (на англ. яз.). DOI: 10.17816/WMO77307

Об авторе: ТАКАТА Токио, почетный профессор Исторического факультета Фуданьского университета (Шанхай, Китай) (takatatokio@gmail.con). 